\title{
Accepting and understanding evolution in Italy: a case study from a selected public attending a Darwin Day celebration
}

\author{
Federica Crivellaro ${ }^{*+}$ and Alessandra Sperduti ${ }^{\dagger}$
}

\begin{abstract}
Background: Public acceptance and understanding of evolution is among the most investigated themes within studies of science and society. In the past decades, scientists and educators have explored acceptance and understanding of the Darwinian theories across a variety of publics, in order to identify possible causal explanations and barriers that make evolution so difficult to be grasped. Indeed, there are both socio-cultural and intuitive reasoning factors which have been widely investigated especially in the USA, a country that shows a widespread resistance. More recently data for Europe, Africa and the Middle East have been published, showing significant differences explained mainly by socio-cultural, religious and political factors. In this respect, the Italian society is still under-investigated. This paper presents and discusses the outcomes of a public survey performed during a Darwin Day celebration in Rome (Italy, February 2013).

Methods: A written questionnaire was submitted to all the participants with the aim of testing attitudes and level of knowledge about evolution among an interested and informed public $(\mathrm{N}=124)$.

Results: The results show that acceptance of evolution is not an issue in such a selected sector of the lay public, although difficulties emerge in the comprehension of some basic principles.

Conclusions: Overall, younger people perform better than respondents older than 65 years, reflecting how science education in Italy has progressed in the latest decades.
\end{abstract}

Keywords: Evolution; Public understanding of science; Evolution acceptance; Darwin Day; Museum studies

\section{Background}

The importance of evolution as a unifying theory able to account for the unity and variability of all present and past living forms (Dobzhansky 1973) is nowadays unanimously accepted among scientists, and it is considered central to scientific literacy, providing for the basics to understand a wide range of topics from biology to medicine, psychology and even climate change (Evans et al. 2010). However, general public attitudes, perceptions and acceptance of evolution lag behind, as shown in a series of international studies that highlight how evolution is indeed difficult to grasp, though with significant differences across nations and types of public (Clément

\footnotetext{
* Correspondence: federica.crivellaro@beniculturali.it

${ }^{\dagger}$ Equal contributors

National Museum of Ethnography and Prehistory "L. Pigorini", P. zza G. Marconi 14, 00144 Rome, Italy
}

and Quessada 2009; Coyne 2012; Miller et al. 2006; Mazur 2005). This is calling for more concrete and targeted actions in order to measure the impact of science outreach, and design new teaching and communication strategies to bridge the gap between science and society. In this respect, surveys are a very important tool to identify lack of knowledge, misconceptions, and other possible causes of non acceptance of evolution, and can help disclose both intrinsic and socially induced difficulties in the understanding of the evolutionary theory.

Questionnaires, polls, interviews, and empirical observations on the learning progress have been performed across different kinds of public, in particular pre-college and college students, but also teachers, museum visitors, and the broad public. Of particular interest are those surveys that have focused on measuring acceptance of evolution and its correlation with other variables such

\section{实 Springer}


as: (a) religious views (Clément et al. 2008; Coyne 2012; Dagher and BouJaoude 1997; Evans 2001; Keranto 2001; McKeachie et al. 2002; Rice et al. 2011; Hokayem and BouJaoude 2008; Rutledge and Warden 1999; Wilson 2010); (b) paranormal beliefs (Eder et al. 2011; Keranto 2001; Losh and Nzekwe 2011); (c) level of knowledge of evolution facts and processes (Bishop and Anderson 1990; Cunningham and Wescott 2009; Demastes et al. 1996; Nehm and Schonfeld 2008); (d) understanding of the Nature of Science (Cunningham and Wescott 2009; Fairchild 2012; Lombrozo et al. 2008; Trani 2004); (e) perception of ethical impact of the Darwinian theory (Brem et al. 2003; Martin-Hansen 2008); (f) logical thinking skills (Pigliucci 2007; Lawson and Weser 1990; Lawson and Worsnop 1992; Sinatra et al. 2003; Woods and Scharmann 2001); (g) exposure to education (LloydStrovas and Beral 2012; Paz-y-Miño and Espinosa 2009; Rice et al. 2011; Wiles and Alters 2011).

The literature is particularly generous for what concerns the factors that contribute to antievolutionary views in individuals of different ages and cultural backgrounds in the United States (see for instance Allmon 2011; Blancke et al. 2012; Thagard and Findlay 2010), where there is a particular public resistance to evolution (Gallup 2012) contrary to Europe (Miller et al. 2006; Clément et al. 2008). More data have been recently gathered also for the European countries (Angus Reid Public Opinion 2010; Athanasiou and Papadopoulou 2012; Carvalho et al. 2012; Ipsos Mori 2009; Southcott and Downie 2012; Williams 2009). In particular, a recent internet-based worldwide survey (Wilson 2010) has shown that Europe stands out for having the highest number of Christians accepting evolution (70\% vs. $36.4 \%$ of non-European Christians). Possible explanations are associated to education systems, or to historical and cultural factors, and certainly to the influence of precise political directions such as those proclaimed by the Council of Europe against creationism and in favour of evolution as a fundamental scientific theory (Council of Europe 2007).

The Italian experience is overall less investigated. Whereas it is included in broader international surveys
(Clément et al. 2008; Miller et al. 2006), it accounts only for a few targeted case studies that vary for goals, methods, and types of public (Berti et al. 2010; Falchetti 2012; Sperduti et al. 2010; Sperduti and Crivellaro 2013; Trevisan 2011; Valente et al. 2008).

In this paper we present and discuss the results of a public survey completed during a Darwin Day celebration in Rome (henceforth Dday) on February 16, 2013, that consisted in a public conference of title "Evolution and Religion", organised by the Department of Philosophy of the University "Roma 3" and the National Museum of Prehistory and Ethnography "Luigi Pigorini". The venue attracted a broad public which, standing from what observed in other similar contexts (Evans et al. 2010; Spiegel et al. 2006), is usually more prone to science in comparison with other publics, has higher education levels, and is receptive to education contents. Although isolated, the Dday sample is an exceptional sample for testing to what extent evolution is really accepted and understood in its Darwinian terms by such an attentive public, adding to the scant literature available at present about the Italian state of affairs. The ultimate goal is to contribute to assess how well evolution is being taught at school and disseminated in more informal contexts, in order to design better solutions and possible new directions to prevail over the innate causal factors that make evolution such a difficult subject to comprehend.

\section{Methods}

\section{Survey design and sample composition}

A written questionnaire was submitted to the public attending the Dday. It consisted of 8 assertions, each with three possibilities of answer (true, false, don't know). The complete list and relative answers are provided in Table 1. These assertions involved different kinds of evolutionary issues, frequently reported as challenging in the literature (e.g. Bishop and Anderson 1990; Gregory 2009; Cunningham and Wescott 2009; Jensen and Finley 1996; Yates and Marek 2013; Wilson 2010), namely: 1. general non-acceptance of evolution; 2. misunderstanding of basic notions of descent with modification and

Table 1 List of assertions and survey results

\begin{tabular}{|c|c|c|c|c|c|}
\hline & Assertion & Answer & $\%$ correct & \% wrong & $\%$ DK \\
\hline A1 & All living species are the result of evolutionary processes & TRUE & 93.5 & 8 & 1.6 \\
\hline A2 & Evolution results in progress & FALSE & 59.7 & 28.2 & 12.1 \\
\hline A3 & Evolution is the gradual transformation of single individuals & FALSE & 59.7 & 29.8 & 10.5 \\
\hline A4 & Evolution is still happening & TRUE & 100 & - & - \\
\hline A5 & Humans and chimps share a common ancestor & TRUE & 85.5 & 8.9 & 5.6 \\
\hline A6 & Humans are the final and best result of evolution & FALSE & 76.6 & 10.5 & 12.9 \\
\hline A7 & Natural selection involves organisms striving to adapt & FALSE & 46.8 & 48.4 & 4.8 \\
\hline A8 & The most recent scientific discoveries contradict evolution & FALSE & 79 & 12.1 & 8.9 \\
\hline
\end{tabular}


natural selection; and 3 . finalistic views and interpretations. The respondents were also asked to provide for some personal information (sex, age, occupation) which was kept minimal to allow donors with more time to focus on the questionnaire and to avoid ethical issues that would have required signed informed consents. No sensitive personal information was collected to protect the respondents' privacy, in accordance with the Italian laws $675 / 1996$ and $196 / 2003$. No minors participated to the survey. Although no time limit was set, the respondents were asked to return the filled in questionnaire before the beginning of the conference, with most of the donors handing back their forms within 10 minutes. The questionnaires were folded as to keep text hidden, and collected in envelops to avoid possible attributions.

A total of 124 respondents (61 females, 53 males, 10 NA) handed back their questionnaires. The youngest donor was 18, the oldest 81 (16 NA), with an average age of 45.3 years. People attending the Roman Dday were for almost a third (32.3\%) from the school and university environment. Given that comparative case studies from the literature focus mainly on students and school teachers, the respondents' occupations were grouped under five categories: 'student' $(\mathrm{N}=25)$; 'school teacher' $(\mathrm{N}=15)$; 'other occupation' $(\mathrm{N}=52)$; 'retired' $(\mathrm{N}=13)$; 'NA' for unanswered cases $(\mathrm{N}=19)$. For analytical purposes, the respondents' age was subdivided into categories of 15 years of interval for a total of 5 categories, namely '<=20' ( $\mathrm{N}=6)$; '21-35' ( $\mathrm{N}=33)$; ‘36-50' ( $\mathrm{N}=25)$; '51-65' $(\mathrm{N}=28)$; '>65' $(\mathrm{N}=16)$. Table 2 provides for a summary of the sample composition.

\section{Data analysis}

All data were analysed by descriptive statistics and by contingency tables for discrete traits. Probability values were scored for three levels of significance: $\mathrm{p} \leqq 0.001$ very highly significant, $\mathrm{p} \leqq 0.01$ highly significant, and $\mathrm{p} \leqq 0.05$ significant. The significance of the interaction between levels for continuous variables was tested by the Tukey's Honest Significant Difference test (Yandell 1997). All the analyses were performed with the $\mathrm{R}$ package 2.15.0 ( $\mathrm{R}$ Development Core Team 2012).

Table 2 Composition of the sample per age-class, gender, and occupation

\begin{tabular}{|c|c|c|c|c|c|c|c|c|c|c|c|c|}
\hline & \multicolumn{2}{|c|}{$<=20$} & \multicolumn{2}{|c|}{$21-35$} & \multicolumn{2}{|c|}{$36-50$} & \multicolumn{2}{|c|}{$51-65$} & \multicolumn{2}{|c|}{$>65$} & \multirow[t]{2}{*}{ NA } & \multirow[t]{2}{*}{ tot } \\
\hline & $M$ & $F$ & $M$ & $F$ & $M$ & $F$ & $M$ & $F$ & $M$ & $F$ & & \\
\hline Student & 4 & 2 & 6 & 12 & & & & & & & 1 & 25 \\
\hline School teacher & & & & 1 & 1 & 5 & 4 & 4 & & & & 15 \\
\hline Other Occupation & & & 6 & 5 & 8 & 9 & 11 & 5 & 3 & 3 & 2 & 52 \\
\hline Retired & & & & & & & 3 & & 10 & & & 13 \\
\hline NA & & & 2 & 1 & 1 & 1 & & 1 & & & 13 & 19 \\
\hline tot & 6 & & 33 & & 25 & & 28 & & 16 & & 16 & 124 \\
\hline
\end{tabular}

The specific issues tested here (see above) were explored by correlating pairs of assertions in the following way: evolution acceptance (pairing A1 and A8), understanding natural selection (A3 and A7), and rejection of the telistic view (A2 and A6). Three different codes were set to measure the respondents' performance, namely: 0 when both assertions were mistaken; 1 when one of the two assertions was correct; and 2 when both assertions were correct. Correlation matrices were run to explore covariance of the three evolutionary issues.

\section{Results and discussion}

The survey was addressed to the lay public attending a Darwin Day event, self selected for being particularly interested to the complex issue debated on that occasion, i.e. the relationship between evolution and religion. Therefore, it does not come as a surprise that the general performance of the respondents is moderately good, with half of the respondents making only one error, or none. Over 992 answers, $74 \%$ are correct, only 18\% are wrong, and 8\% unanswered (henceforth DK). Overall, $20.2 \%$ of the total answered correctly to all questions, with another $28.2 \%$ answering correctly to 7 of the 8 assertions. In total, $67.7 \%$ of the sample answered correctly to at least 6 assertions, whereas only less than a quarter (22.6\%) answered correctly to less than 4 assertions. Nobody failed the questionnaire completely. Detailed figures for each assertion are provided in Table 1.

Correctness is statistically significant when correlated with age and occupation, but not with sex. In particular, multiple comparisons of means (Tukey's test) give high statistical significance for the contrast between age categories $21-35$ and $>65(\mathrm{p} \leqq 0.001)$, and between occupied and retired respondents $(\mathrm{p} \leqq 0.05)$. Figure 1 illustrates correctness values per each subset, in both cases highlighting a contrastive median value of 4 correct answers for the age class $>65$.

The analysis of performance per single assertion shows different behaviours within the sample, ranging from $100 \%$ of correct answers for A4 (Evolution is still happening) - and hence excluded from the analysis, to a minimum of $41.6 \%$ of correct answers for A7 (Natural selection involves organisms striving to adapt). Whether this result highlights substantial differences in the level of acceptance of evolution versus a thorough understanding of its mechanisms will be discussed below.

\section{Acceptance of evolution}

General acceptance of evolution was evaluated through the answering pattern of the assertions: A1 (All living species are the result of evolutionary processes) and A8 (The most recent scientific discoveries contradict evolution). In our sample, degree of acceptance is quite high: $88.7 \%$ of the sample answered correctly to at least one 


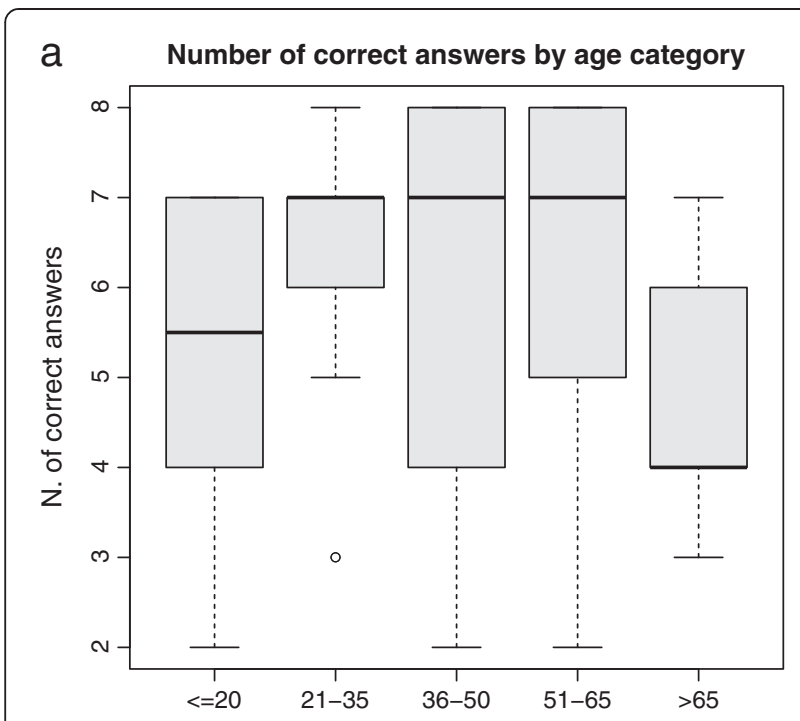

b Number of correct answers by occupation

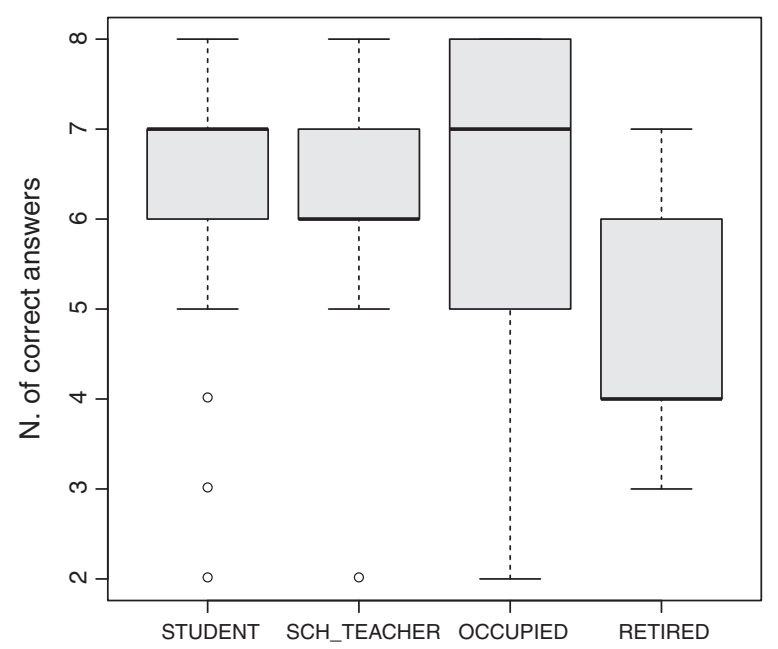

Figure 1 Box-plot graphs illustrating the performance of the DDay (a) per age class, and (b) per category of occupation. The graphs show the distribution of correct answers across

subcategories of the surveyed population. The boxes contain the $50 \%$ of the observations, while whiskers represent maximum and minimum values. The bold line shows median values. Outliers are shown as empty circles.

question and $74.2 \%$ to both. Also, when asked about the evolutionary origin of human beings (A5), the Dday sample shows a high level of acceptance (85.5\%).

This result is not in contrast with what already observed in the cross-national survey by Miller et al. (2006) in which more than $66 \%$ of the Italian respondents deem true that "Human beings, as we know them, developed from earlier species of animals". The survey by Clément et al. (2008) also confirms that Italian teachers - especially those teaching biology - have a generally high level of acceptance of evolution, compared with colleagues from Europe, Africa and the Middle East. Other surveys focused on the Italian students (Berti et al. 2010; Sperduti et al. 2010; Sperduti and Crivellaro 2013; Trevisan 2011) further highlight how the teaching of evolution across all school levels (elementary, middle, and high) - as foreseen in the Italian curricula - would favour awareness and acceptance of the evolutionary theory.

\section{Understanding evolution}

A thorough comprehension of evolution implies the understanding of some key concepts of natural selection, e. g. individual and population variation, descent with modification, and differential survival fitness (Nehm and Schonfeld 2010; Pigliucci and Kaplan 2006; van Dijk and Reydon 2010). Natural selection is often wrongly perceived in Lamarckian terms, where evolution implies individual efforts and modifications in order to adapt to changing environments (Banet and Ayuso 2003; Bishop and Anderson 1990; Bardapurkar 2008; Dagher and BouJaoude 1997; Evans 2000, 2001; Gregory 2009; Nehm and Reilly 2007; Shtulman 2006). This misconception has already been addressed as one particularly resistant to instruction across different types of samples, including pre-college and college students, as well as teachers (Asghar et al. 2007; Bardapurkar 2008; Gregory 2009; Nehm and Reilly 2007; Rutledge and Warden 2000; Saul et al. 2002; Sperduti and Crivellaro 2013; but see also Nadelson and Sinatra 2009; Beggrow and Nehm 2012; Nehm and Ridgway 2011). Even among those who accept evolution, misunderstanding occurs (Sinatra et al. 2003; Smith and Siegel 2004; Evans et al. 2012). Also in our sample, where acceptance of evolution does not seem an issue, comprehension of the underlying mechanisms of natural selection is slightly more challenging. We tested this variable through the answering pattern of assertions A3 (Evolution is the gradual transformation of single individuals) and A7 (Natural selection involves organisms striving to adapt). Indeed, only $37.7 \%$ of the sample answered correctly to both questions, $38.7 \%$ to at least one, and $23.6 \%$ to none.

These results would confirm that even an interested public that accepts the Darwinian theory is, to some degrees, inclined to perceive evolution through the reading of "individual transformations" rather than variation at population level (Mayr 2001). Indeed, assertion A7 proved to be the most challenging in our sample, with erroneous assessments registered across all age classes though with a clear drop in performance for the oldest (chisq $=11.1 ; \mathrm{p} \leqq 0.05)$. This erroneous concept stems on strong intuitive beliefs, such as the teleological, essentialist and anthropocentric thinking (Coley and Tanner 2012; Opfer et al. 2012), as well as the notion of intentionality or "agency" (Evans 2008; Kelemen and 
Rosset 2009). These cognitive construals lead to the idea that each organism has a willingness, as well as the capability, to change and adapt in order to survive in a particular environment (Werth 2012), therefore adapting is perceived as a behavior directed towards a specific goal (Tomasello et al. 2005).

\section{The misconception of evolution as progress}

Assertions A2 (Evolution results in progress) and A6 (Human beings are the final and best result of evolution) were intended to test the presence of cultural and intuitive views related to the misconception of evolution as a finalistic process, centred around an anthropocentric viewpoint. With the exclusion of the DK answers, 59.6\% of the respondents answered correctly to both questions, $20.2 \%$ to at least one, and another $20.2 \%$ to none. The correlation with age classes gives similar results to what observed in the previous section (chisq $=15.7 ; \mathrm{p} \leqq 0.05)$.

It is often argued that people tend to consider all evolutionary changes as adaptive, progressive, and optimal, since it is cognitively hard avoiding the idea that evolutionary changes bring an inevitable progress (Ruse 1997; Carroll 2001). Furthermore, conceptually there is a tendency to link the idea of "new" with "improved", as well as to attribute values of low esteem ("lower", "less evolved") to species that are phylogenetically more distant to human beings (Werth 2012). The idea of evolution as progress - culminating with the emergence of a "more evolved" species (Homo sapiens) - is wrongly reinforced by social images of distorted evolutionary trees and of linear progressions of hominin species, constantly provided in books, web-sites, commercials, cartoons, and (regrettably) museum exhibitions too. The very same images, carrying implicit erroneous values, are also frequently reported in school textbooks (Quessada et al. 2008) and do not help in the correct understanding of evolution at large.

\section{Correlation between evolution acceptance and understanding}

As stated before, a positive correlation between acceptance and understanding of evolution is not ubiquitous (Deniz et al. 2008; Brem et al. 2003; Cunningham and Wescott 2009; Meadows et al. 2000; Rutledge and Warden 2000; Sinatra et al. 2003; Smith and Siegel 2004; Southerland and Sinatra 2005; Valente et al. 2008). In order to explore whether evolution acceptance implies a correct comprehension of the basic principles of evolution in the Dday sample, a pairwise correlation analysis was performed to detect possible associations between the three themes analysed above - 1. evolution acceptance, 2. understanding natural selection, and 3. rejection of the telistic view (chisq $=286.22 ; \mathrm{p} \leqq 0.001)$. Indeed, there is a positive correlation between the answering patterns

Table 3 Correlation between acceptance and understanding of evolution

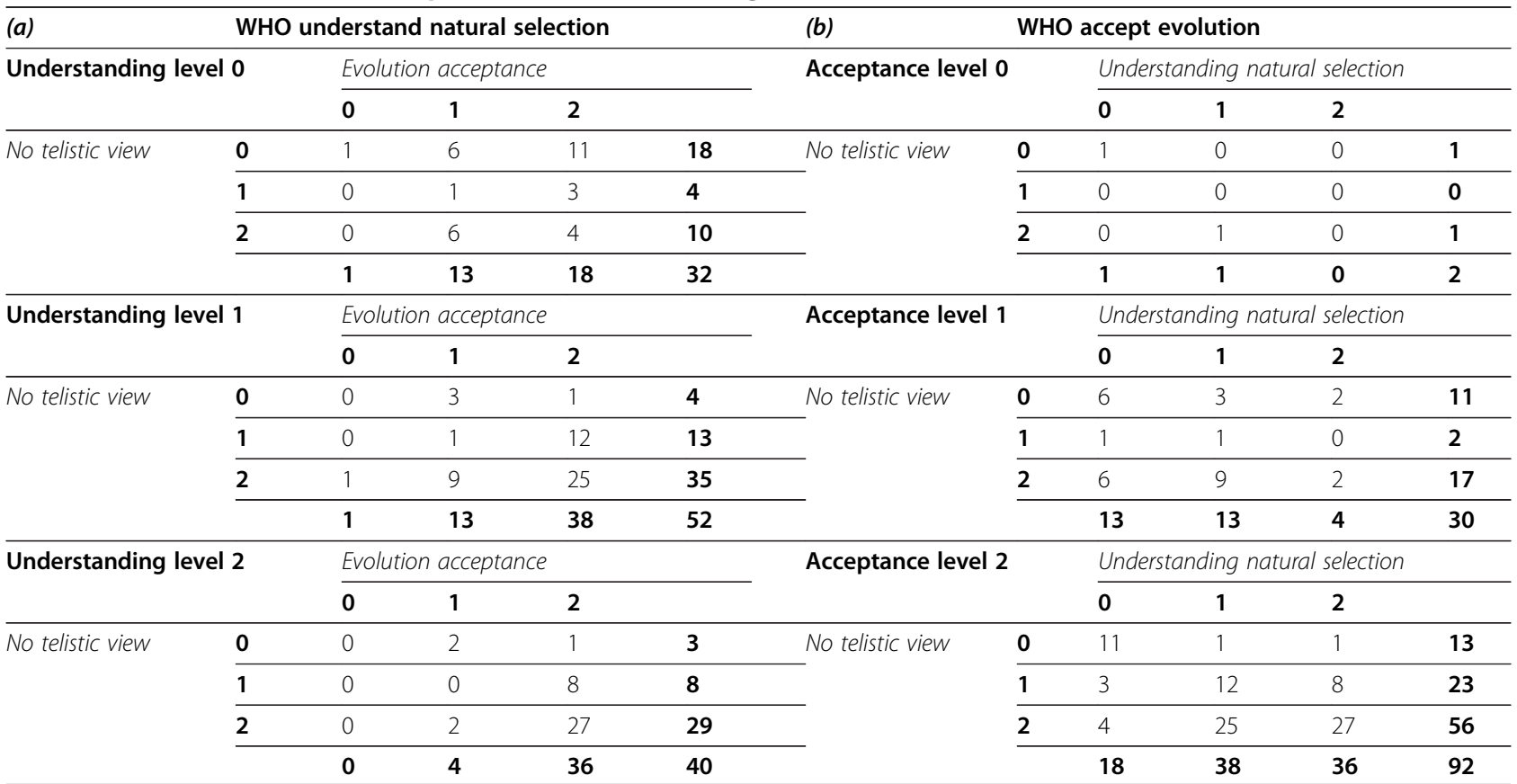

Pairwise correlation matrix between variables (evolution acceptance, understanding natural selection, and rejection of the telistic view), aimed at revealing different answering patterns across the Dday sample $(\mathrm{N}=124)$. Table 3a shows three matrices derived from the correlation between 'evolution acceptance' and 'rejection of the telistic view', tested for the actual 'understanding of natural selection'. Table $3 \mathrm{~b}$ accounts for the pairwise correlation between 'understanding of natural selection' and 'rejection of the telistic view', tested according to the level of 'evolution acceptance'. The two sets of tables highlight that whether a better comprehension of evolution implies evolution acceptance, the opposite is not true - with people accepting evolution not necessarily understanding its mechanisms. Read codes in bold: $\mathbf{0}=$ both assertions mistaken; $\mathbf{1}=$ one of the two assertions is correct; $\mathbf{2}=$ both assertions are correct. 
of variable 2 and 3 (chisq $=35.3 ; \mathrm{p} \leqq 0.001$ ) which shows that respondents misconceiving natural selection tend to have a telistic view of evolution as well - although the former seems to be more of an issue than the latter (39.1\% vs. $60.9 \%$ of correct answers).

Our results show that of those who completely accept evolution $(\mathrm{N}=92)$ only the $29.4 \%$ have a full comprehension, while another $35.9 \%$ are less comfortable in comprehending well either natural selection or the telistic misconception. Conversely, $34.8 \%$ have a fragmented understanding, variously mistaking the combination of pairs of answers as illustrated in Table 3 - and a third of them mistaking all four questions.

However, when analysing the pairwise correlation between variable 1 and 3 , tested for different grades of comprehension of natural selection, we see that acceptance of evolution is almost universal (99\%). This confirms that understanding evolution can be predictive of its acceptance, but not vice versa.

\section{Conclusions}

Public acceptance of evolution in Italy is still underinvestigated, and we are still far from having a clear and complete picture. However, the results of this survey provide with valuable information, especially if interpreted in a broader perspective that takes into account evidence from similar research in our country. The Dday sample shows that not all of those who accept evolution grasp it completely. Indeed, some of the respondents have a fragmented understanding that occurs as a blend of correct evolutionary concepts, intuitive misbeliefs, and naïve conceptions induced by common social representations.

The scenario emerging from the - though limited number of surveys in Italy seems to indicate that rejection of the evolutionary theory is not widespread, nor deeply rooted in the Italian society. This might be positively associated to an early exposure to the evolutionary theory since the elementary grades in the Italian school system - although at this stage evolution is taught only within the history curricula, as a series of facts and processes based on the fossil evidence. USA scholars are calling for similar educational strategies in their school system (e.g. Wagler 2010, 2012; Williams 2009), claiming that it would highly prevent the build-up of preconceptions and mis-conceptions, so difficult to correct at later educational stages (Kampourakis and Zogza 2009; Nadelson et al. 2009). However, although the Italian school seems to be prone to an early encounter with the Darwinian theory, it is not providing for sufficiently effective tools to ensure a thorough and clear understanding of its facts and mechanisms. In this respect, a larger responsiveness of the scientific community would help find more effective ways to communicate evolution to both the school and the general public.

\section{Authors' contributions}

Both authors (FC and AS) equally participated in the study design, data analysis and writing of the manuscript. Both authors read and approved the final manuscript.

\section{Acknowledgements}

The authors are indebted to Ines Adornetti for important discussions while conceiving the study, and to Francesco Ferretti and Luca Bondioli for support in the preparation of the manuscript. A special thank to Antonella Frigerio, Francesca Marino, Chiara Reggio, Prisca Solaini, and Serena Vaccaro who actively participated to the data collection during the Dday event. The study was supported by the Italian Ministry of Research and Education (MIUR) grant ACPR12_00134.

Received: 23 November 2013 Accepted: 15 April 2014

Published online: 21 May 2014

\section{References}

Allmon, WD. (2011). Why don't people think evolution is true? Implications for teaching, in and out of the classroom. Evolution: Education and Outreach, 4, 648-665

Angus Reid Public Opinion. (2010). Americans are creationists; Britons and Canadians side with evolution. http://www.angus-reid.com/wp-content/ uploads/2012/09/2012.09.05_CreEvo.pdf Accessed 16 September 2013.

Asghar, A, Wiles, JR, \& Alters, B. (2007). Canadian preservice elementary teachers' conceptions of biological evolution and evolution education. McGill Journal of Education, 42, 189-209.

Athanasiou, K, \& Papadopoulou, P. (2012). Conceptual ecology of the evolution acceptance among Greek education students: knowledge, religious practices and social influences. International Journal of Science Education, 34, 903-924.

Banet, E, \& Ayuso, GE. (2003). Teaching of biological inheritance and evolution of living beings in secondary school. International Journal of Science Education, 25, 373-407.

Bardapurkar, A. (2008). Do students see the "selection" in organic evolution? A critical review of the causal structure of student explanations. Evolution: Education and Outreach, 1, 299-305.

Beggrow, EP, \& Nehm, RH. (2012). Students' mental models of evolutionary causation: natural selection and genetic drift. Evolution: Education and Outreach, 5, 429-444.

Berti, AE, Toneatti, L, \& Rosati, V. (2010). Children's conceptions about the origin of species: a study of Italian children's conceptions with and without instruction. Journal of Learning Sciences, 19, 506-538.

Bishop, B, \& Anderson, C. (1990). Student conceptions of natural selection and its role in evolution. Journal of Research in Science Teaching, 27, 415-427.

Blancke, S, De Smedt, J, De Cruz, H, Boudry, M, \& Braeckman, J. (2012). The implications of the cognitive sciences for the relation between religion and science education: the case of evolutionary theory. Science \& Education, 21, 1167-1184

Brem, SK, Ranney, M, \& Schindel, J. (2003). Perceived consequences of evolution: college students perceive negative personal and social impact in evolutionary theory. Science Education, 87, 181-206.

Carroll, S. (2001). Chance and necessity: the evolution of morphological complexity and diversity. Nature, 409, 1102-1109.

Carvalho, GS, Tracana, RB, Silva, PR, Araùjo, E, \& Caldera, AM. (2012). The influence of religion in Portugese and Brasilian teachers' conception about the origin of life. In C Bruguière, A Tiberghien, \& P Clément (Eds.), eBook proceedings of the ESERA 2011 Conference-Science Learning and Citizenship. Part 11: Cultural, Social and Gender issues (pp. 6-11).

Clément, P, \& Quessada, M-P. (2009). Creationist beliefs in Europe. Science, $324,1644$.

Clément, P, Quessada, M-P, Laurent, C, \& Carvalho, G. (2008). The use of Science and Technology Education for Peace and Sustainable Development Science and Religion: Evolutionism and Creationism in Education. A survey of teachers conceptions in 14 countries. XIII IOSTE Symposium, Izmir (Turkey), 21-26 September 2008. http://repositorium.sdum.uminho.pt/bitstream/1822/8934/1/ IOSTE_Evolution.pdf. Accessed 2 September 2013. 
Coley, JD, \& Tanner, KD. (2012). Common origins of diverse misconceptions: cognitive principles and the development of biology thinking. CBE-Life Sciences Education, 11, 209-215.

Council of Europe. (2007). The dangers of creationism in education. Parliamentary Assembly Document Number 11375. http://assembly.coe.int/main.asp?link=/ documents/adoptedtext/ta07/eres1580.htm. Accessed 16 September 2013.

Coyne, JA. (2012). Science, religion, and society: the problem of evolution in America. Evolution, 66, 2654-2663.

Cunningham, DL, \& Wescott, DJ. (2009). Still more "fancy" and "myth" than "fact" in students' conceptions of evolution. Evolution: Education and Outreach, 2, 505-517.

Dagher, ZR, \& BouJaoude, S. (1997). Scientific views and religious beliefs of college students: the case of biological evolution. Journal of Research in Science Teaching, 34, 429-445.

Demastes, SS, Good, RG, \& Peebles, P. (1996). Patterns of conceptual change in evolution. Journal of Research in Science Teaching, 33, 407-431.

Deniz, H, Donnelly, LA, \& Yilmaz, I. (2008). Exploring the factors related to acceptance of evolutionary theory among Turkish preservice biology teachers: toward a more informative conceptual ecology for biological evolution. Journal of Research in Science Teaching, 45, 420-443.

Dobzhansky, T. (1973). Nothing in biology makes sense except in the light of evolution. The American Biology Teacher, 35, 125-129.

Eder, E, Turic, K, Milasowszky, N, Van Adzin, K, \& Hergovich, A. (2011). The relationships between paranormal belief, creationism, intelligent design and evolution at secondary schools in Vienna (Austria). Science \& Education, 20, 517-534.

Evans, EM. (2000). The emergence of beliefs about the origins of species in school-age children. Merrill-Palmer Quarterly, 46, 221-254.

Evans, EM. (2001). Cognitive and contextual factors in the emergence of diverse belief systems: creation versus evolution. Cognitive Psychology, 42, 217-266.

Evans, EM. (2008). Conceptual change and evolutionary biology: a developmental analysis. In S Vosniadou (Ed.), International handbook of research on conceptual change (pp. 263-294). New York: Routledge.

Evans, EM, Spiegel, AN, Gram, W, Frazier, BN, Tare, M, Thompson, S, \& Diamond, J. (2010). A conceptual guide to natural history museum visitors' understanding of evolution. Journal of Research in Science Teaching, 47, 326-353.

Evans, EM, Rosengren, K, Lane, JD, \& Price, KS. (2012). Encountering counterintuitive ideas: constructing a developmental learning progression for biological evolution. In KR Rosengren, S Brem, EM Evans, \& G Sinatra (Eds.), Evolution Challenges: Integrating research and practice in teaching and learning about evolution (pp. 174-199). New York: Oxford University Press.

Fairchild, NR. (2012). The effect of instruction bases on the nature of science and eliminating preconceptions on understanding and acceptance evolution. Master thesis. Bozeman, Montana: Montana State University. http://etd.lib.montana. edu/etd/2012/fairchild/FairchildN0812.pdf. Accessed 10 September 2013.

Falchetti, EM. (2012). Biological evolution on display: an approach to evolutionary issues through a museum. Evolution: Education and Outreach, 5, 104-122.

Gallup. (2012). In U.S., 46\% hold creationist view of human origins. Gallup Poll web site. http://www.gallup.com/poll/155003/Hold-Creationist-View-HumanOrigins.aspx. Accessed 10 September 2013.

Gregory, TR. (2009). Understanding natural selection: essential concepts and common misconceptions. Evolution: Education and Outreach, 2, 156-75.

Hokayem, H, \& BouJaoude, S. (2008). College students' perceptions of the theory of evolution. Journal of Research in Science Teaching, 45, 395-419.

Ipsos Mori. (2009). Project Darwin Omnibus - Great Britain. http://www.ipsos-mori. com/Assets/Docs/Polls/poll-darwin-survey-shows-international-consensus-onacceptance-of-evolution.pdf. Accessed 16 September 2013.

Jensen, MS, \& Finley, FN. (1996). Changes in students' understanding of evolution resulting from different curricular and instructional strategies. Journal of Research in Science Teaching, 33, 879-900.

Kampourakis, K, \& Zogza, V. (2009). Preliminary evolutionary explanations: a basic framework for conceptual change and explanatory coherence in evolution. Science \& Education, 18, 1313-1340.

Kelemen, D, \& Rosset, E. (2009). The human function compunction: teleological explanation in adults. Cognition, 111, 138-143.

Keranto, T. (2001). The perceived credibility of scientific claims, paranormal phenomena, and miracles among primary teacher students: a comparative study. Science \& Education, 10, 493-511.

Lawson, AE, \& Weser, J. (1990). The rejection of nonscientific beliefs about life: effects of instruction and reasoning skills. Journal of Research in Science Teaching, 27, 589-606.
Lawson, AE, \& Worsnop, WA. (1992). Learning about evolution and rejecting a belief in special creation: effects of reasoning skill, prior knowledge, prior belief and religious commitment. Journal of Research in Science Teaching, 29, 143-66.

Lloyd-Strovas, JD, \& Bernal, XE. (2012). A review of undergraduate evolution education in U.S. universities: building a unifying framework. Evolution: Education and Outreach, 5, 453-465.

Lombrozo, T, Thanukos, A, \& Weisberg, M. (2008). The importance of understanding the nature of science for accepting evolution. Evolution: Education and Outreach, 1, 290-298.

Losh, SC, \& Nzekwe, B. (2011). Creatures in the classroom: preservice teacher beliefs about fantastic beasts, magic, extraterrestrials, evolution and creationism. Science \& Education, 20, 473-489.

Martin-Hansen, LM. (2008). First-year college students' conflict with religion and science. Science \& Education, 17, 317-357.

Mayr, E. (2001). What evolution is. New York: Basic Books.

Mazur, A. (2005). Believers and disbelievers in evolution. Politics and the Life Science, 23, 55-61.

McFadden, BJ, Dunckel, BA, Ellis, S, Dierking, LD, Abraham-Silver, L, Kisiel, J, et al. (2007). Natural history museum visitors' understanding of evolution. Bioscience, 57, 875-82.

McKeachie, WJ, Lin, YG, \& Strayer, J. (2002). Creationist vs. evolutionary beliefs: effects on learning biology. The American Biology Teacher, 64, 189-192.

Meadows, L, Doster, E, \& Jackson, DF. (2000). Managing the conflict between evolution \& religion. The American Biology Teacher, 62, 102-107.

Miller, JD, Scott, EC, \& Okamoto, S. (2006). Public acceptance of evolution. Science, $313,765-766$.

Nadelson, LS, \& Sinatra, GM. (2009). Educational professionals' knowledge and acceptance of evolution. Evolutionary Psychology, 7, 490-516.

Nadelson, L, Culp, R, Bunn, S, Burkhart, R, Shetlar, R, Nixon, K, \& Waldron, J. (2009). Teaching evolution concepts to early elementary school students. Evolution: Education and Outreach, 2, 458-473.

National Research Council. (2011). A framework for k-12 science education: practices, crosscutting concepts, and core ideas. Washington: National Academy.

Nehm, RH, \& Reilly, L. (2007). Biology majors' knowledge and misconceptions of natural selection. Bioscience, 57, 263-272.

Nehm, RH, \& Ridgway, J. (2011). What do experts and novices "see" in evolutionary problems? Evolution: Education and Outreach, 4, 666-679.

Nehm, RH, \& Schonfeld, IS. (2008). Measuring knowledge of natural selection: a comparison of the CINS, an open-response instrument, and an oral interview. Journal of Research in Science Teaching, 45, 1131-1160.

Opfer, JE, Nehm, RH, \& Ha, M. (2012). Cognitive foundations for science assessment design: knowing what students know about evolution. Journal of Research in Science Teaching, 49, 744-777.

Paz-y-Miño-C, G, \& Espinosa, A. (2009). Acceptance of evolution increases with student academic level: a comparison between a secular and a religious college. Evolution, 2, 655-675.

Pigliucci, M. (2007). The evolution-creation wars: why teaching more science just is not enough. McGill Journal of Education, 42, 285-306.

Pigliucci, M, \& Kaplan, J. (2006). Making sense of evolution: The conceptual foundations of evolutionary biology. Chicago: University of Chicago Press.

Quessada, M-P, Clément, P, Oerke, B, \& Valente, A. (2008). Human evolution in science textbooks from twelve different countries. Science Education International, 19, 147-162.

R Development Core Team. (2012). R: A language and environment for statistical computing. Vienna, Austria: R Foundation for Statistical Computing. http:// www.R-project.org.

Rice, JW, Olson, JK, \& Colbert, JT. (2011). University evolution education: the effect of evolution instruction on biology majors' content knowledge, attitude toward evolution, and theistic position. Evolution: Education and Outreach, 4, 137-144.

Ruse, M. (1997). Monad to man: the concept of progress in evolutionary biology. Cambridge: Harvard University Press.

Rutledge, M, \& Warden, M. (1999). The development and validation of the measure of acceptance of the theory of evolution instrument. School Science and Mathematics, 99, 13-18.

Rutledge, M, \& Warden, M. (2000). Evolutionary theory, the nature of science \& high school biology teachers: Critical relationships. The American Biology Teacher, 62, 23-31. 
Saul, C, Munford, D, Crawford, B, Friedrichsen, P, \& Land, S. (2002). Scaffolding preservice science teachers' evidence-based arguments during an investigation of natural selection. Research in Science Education, 32, 437-463.

Shtulman, A. (2006). Qualitative differences between naïve and scientific theories of evolution. Cognitive Psychology, 52, 170-194.

Sinatra, GM, Southerland, SA, McConaughy, F, \& Demastes, JW. (2003). Intentions and beliefs in students' understanding and acceptance of biological evolution. Journal of Research in Science Teaching, 40, 510-528.

Smith, MU, \& Siegel, H. (2004). Knowing, believing, and understanding: what goals for science education? Science \& Education, 13, 553-582.

Southcott, R, \& Downie, JR. (2012). Evolution and religion: attitudes of Scottish bioscience students to the teaching of evolutionary biology. Evolution: Education and Outreach, 5, 301-311.

Southerland, SA, \& Sinatra, GM. (2005). The shifting roles of acceptance and dispositions in understanding biological evolution. In S Alsop (Ed.), Beyond Cartesian dualism: Encountering affect in the teaching and learning of science (pp. 69-78). Dordrecht, The Netherlands: Springer.

Sperduti, A, \& Crivellaro, F. (2013). Before and after: students' learning achievements on brain, language, and evolution. Procedia - Social and Behavioral Sciences, 116, 2100-2104.

Sperduti, A, Rossi, PF, \& Bondioli, L. (2010). La didattica dell'evoluzione umana nelle scuole elementari. II progetto "Sospesi al Ramo di un albero" del Museo L. Pigorini. Museologia Scientifica, 6, 231-236.

Spiegel, AN, Evans, EM, Gram, W, \& Diamond, J. (2006). Museum visitors' understanding of evolution. Museums \& Social Issues, 1, 67-84.

Thagard, P, \& Findlay, S. (2010). Getting to Darwin: obstacles to accepting evolution by natural selection. Science \& Education, 19, 625-636.

Tomasello, M, Carpenter, M, Call, J, Behne, T, \& Moll, H. (2005). Understanding and sharing intentions: the origins of cultural cognition. Behavioral and Brain Science, 28, 675-735.

Trani, R. (2004). I won't teach evolution: it's against my religion. And now for the rest of the story. The American Biology Teacher, 66, 419-427.

Trevisan, T. (2011). Metodologie didattiche nellinsegnamento della teoria evoluzionistica. Master Thesis, University of Padua. http://paduaresearch.cab. unipd.it/3558/1/ metodologie_didattiche_nell'insegnamento_della_teoria_evoluzionistica.pdf. Accessed 16 November 2013.

Valente, A, Cerbara, L, Caravita, S, \& Luzi, D. (2008). Conceptions on evolution in teachers and future teachers: results of an Italian investigation. XIII IOSTE Symposium, the Use of Science and Technology Education for Peace and Sustainable Development. September 21-26, Kusadasi, Turkey, 2008.

van Dijk, EM, \& Reydon, TAC. (2010). A conceptual analysis of evolutionary theory for teacher education. Science \& Education, 19, 655-677.

Wagler, R. (2010). A missing link: K-4 biological evolution content standards. Evolution: Education and Outreach, 3, 443-50.

Wagler, R. (2012). Assessing "the framework" for kindergarten through fifth grade biological evolution. Evolution: Education and Outreach, 5, 274-278.

Werth, A. (2012). Avoiding the pitfall of progress and associated perils of evolutionary education. Evolution: Education and Outreach, 5, 249-265.

Wiles, JR, \& Alters, B. (2011). Effects of an educational experience incorporating an inventory of factors potentially influencing student acceptance of biological evolution. International Journal of Science Education, 33, 2559-2585.

Williams, JD. (2009). Belief versus acceptance: why do people not believe in evolution? BIO-Essays, 31, 1255-1262.

Wilson, DP. (2010). European Christians are at the forefront in accepting evolution: results from an internet-based survey. Evolution \& Development, 12, $537-540$.
Woods, CS, \& Scharmann, LC. (2001). High school students' perceptions of evolutionary theory. Electronic Journal of Science Education, 6. http://wolfweb. unr.edu/homepage/crowther/ejse/westerlundetal.html. Accessed 16 October 2013.

Yandell, BS. (1997). Practical Data Analysis for Designed Experiments. London: Chapman \& Hall.

Yates, TB, \& Marek, EA. (2013). Is Oklahoma really OK? A regional study of the prevalence of biological evolution-related misconceptions held by introductory biology teachers. Evolution: Education and Outreach. doi:10.1186/ 1936-6434-6-6.

\section{doi:10.1186/s12052-014-0013-4}

Cite this article as: Crivellaro and Sperduti: Accepting and understanding evolution in Italy: a case study from a selected public attending a Darwin Day celebration. Evolution: Education and Outreach 2014 7:13.

\section{Submit your manuscript to a SpringerOpen ${ }^{\odot}$ journal and benefit from:}

- Convenient online submission

Rigorous peer review

- Immediate publication on acceptance

- Open access: articles freely available online

- High visibility within the field

- Retaining the copyright to your article

Submit your next manuscript at $\gg$ springeropen.com 